\title{
EDITORIAL: Ruthless tidal wave
}

- HIS edition of Pacific Journalism Review began with a theme around 'Endangered Journalists'. However, by the time it was into full editorial production it was clear that this was also about the global silence and injustice imposed on West Papua and the 'endangered' indigenous people in this mountainous land on the cusp of Asia and the Pacific.

While the edition layout was being prepared, remarkable events were happening in West Papua and elsewhere in Indonesia this year around the historically significant anniversary date of 1 May 2016 - fifty-three years after a United Nations Temporary Executive Authority (UNTEA) handed power over the former Dutch colony in West New Guinea to Jakarta with a mandate to rule until such time as the Papuan people decided on their future in a free vote.

Instead, the sham 'Act of Free Choice' was orchestrated in 1969 with a handpicked group of 1050 men and women (out of a population at the time of more than 800,000 people) who were publicly coerced into choosing to be incorporated into the Republic of Indonesia.

Such critical dates as this - and 1 December 1961, when colonial Ordinances came into force recognising Papuan 'independence' with a Dutch blessing, a Manifesto, a national flag (the striking Morning Star, which is banned in Indonesia), and a national anthem ('Oh My Land Papua')—-have been observed every year since an Indonesian paratroop invasion in January 1962.

However, in May 2016 a wave of mass 'pre-emptive' arrests engulfed hundreds of activists. It demonstrated without a doubt the compelling popular support among Papuans for self-determination and how this has been steadily growing stronger over the past half century, partly fuelled by recent social media campaigns by solidarity groups around the globe. As an advocate for the Jakarta Legal Aid Institute, Veronica Koman, wrote in The Jakarta Post:

In early May, 2109 Papuan independence protesters were arrested by police - and that number is more than double the 1025 who were pressganged into legitimising Indonesia's rule of Papua through the 1969 'Act of Free Choice'.

Despite our Indonesian Embassy in the United Kingdom denying in The Guardian that the arrests took place, the Jakarta Legal Aid Institute documented them all, and holds the names of every one of the 2109 demonstrators ...

This is the historical reality that underpins today's grievances about state violence, environmental degradation and suppression of free speech in Papua.

Until these grievances are addressed, argues Koman, the protests by Papuans 
will continue and the numbers will continue to grow. She notes that, according to her agency's records, as at mid-May 2016, 'the figure stands at 2282 peaceful demonstrators detained by police'.

Also happening in this eventful month was an extraordinary meeting of more than 100 parliamentarians, politicians, civil rights lawyers and activists from some 23 countries who gathered in London to adopt the Westminster Declaration, which branded the 1969 vote as a 'gross violation of the right to self-determination'. It also called for an internationally supervised referendum in Papua.

As I have commented elsewhere, reporting of both Timor Leste and West Papua over several decades has been, and still is, a 'highly risky business', as evinced by the killing of six Australian-based journalists- the so-called Balibó Five and then Roger East who went there to investigate their deaths-during the invasion of East Timor in 1975 (immortalised in the 2009 Robert Connolly feature film Balibó, www.balibo.com) (Robie, 2013).

In July 2014, Green Party MP Catherine Delahunty stunned the New Zealand Parliament with an untabled motion calling on the then new Indonesian President Joko Widodo to 'commit to genuine media freedom' in West Papua, 'including the right of local and international journalists to report there without risk of imprisonment or harassment'. Her motion won unanimous cross-party support (Robie, 2014).

This misleading new leaf-turning by Widodo led to the first television crew from New Zealand in half a century travelling to West Papua in August-Māori Television's Native Affairs reporter Adrian Stevanon with Pacific Media Centre researcher Karen Abplanalp were followed by a Radio New Zealand International team, Johnny Blades and Koroi Hawkins, in October. While this opened up some light on developments in West Papua for a New Zealand audience-Stevanon managed an intriguing report on an aid-funded kumara production project in the Highlands - they were still stage-managed media visits in many respects.

A Catholic Justice and Peace Commission fact-finding mission from Australia visited West Papua earlier this year, in lieu of the Pacific Islands Forum summit's initiative decided at the Port Moresby summit in September 2015-but blocked by Indonesian authorities - and produced a devastating report in May that called for urgent action to support Papuans who were 'living with unrelenting intimidation and brutality' (Archdiocese of Brisbane, 2016). The report said:

The situation in West Papua is fast approaching a tipping point. In less than five years, the position of Papuans in their own land will be worse than precarious. They are already experiencing a demographic tidal wave. Ruthless Indonesian political, economic, social and cultural domination threatens to engulf the proud people who have inhabited the land they call Tanah Papua for thousands of years. (Ibid., p. 2) 
The report was equally damning on issues of freedom of expression and the media, concluding:

Despite an announcement in May 2015 by President Widodo that journalists would have free access to West Papua, media access is still restricted. There is no freedom of expression. Almost 40 political prisoners are currently in jail [written before the 2000 plus arrests on May 1/2 this year], customary land rights are not protected and there is no systemic policy of affirmative action. West Papuan human rights are also not protected. Throughout 2015, the Indonesian security forces have targeted young people in particular, all of whom have been unarmed. (Ibid., p. 11)

The implications for freedom of expression and the press, and safety of journalists, in West Papua is obscured by various global media freedom reports which effectively hide the region (the two provinces of Papua and West Papua) in the body of their dossier. According to Reporters Sans Frontières (RSF) 2016 World Press Freedom Index, Indonesia was 130th out of 180 nations surveyed and the report noted Widodo's presidency continued to be 'marked by serious media freedom violations, including lack of access to West Papua, a media freedom black hole.' The report continued:

Journalists and fixers working there are liable to be arrested. The problem is compounded by Indonesia's visa law, which discriminates against foreign journalists. At the same time, many poorly paid journalists accept bribes in return for positive coverage. (RSF, 2016)

In Freedom House's latest World Press Freedom report on Indonesia, the West Papuan situation also comes in for criticism:

Media coverage of the sensitive issue of Papuan separatism continued to draw special scrutiny and restrictions from the government ... Before taking office, President Widodo pledged that he would allow international journalists and organisations access to Papua and West Papua; however, this did not happen by year's end. The Indonesian authorities effectively block foreign media from reporting in the two provinces by restricting access to those with official government approval, which is rarely granted. The few journalists who do gain permission are closely monitored by government agents, who control their movements and access to local residents. (Freedom House, 2015)

According to Human Rights Watch, 'the military has also financed and trained journalists and bloggers, citing alleged foreign interference in the region, including by the US government' (Ibid.) 
Following the mass arrests in early May, RSF issued a communique calling on the Indonesian government to 'stop violating the rights of journalists in West Papua'. It particularly condemned the Jayapura police for preventing reporters from covering a peaceful demonstration in support of the United Liberation Movement for West Papua on May 2 -ironically, the eve of World Press Freedom Day. The communique said:

\begin{abstract}
Ardi Bayage, a journalist working for the Suarapapua.com news website, was arrested at the same time as other protesters although he showed his press card to the police. The authorities, who accused him of lying, broke his mobile phone and took him to the mobile brigade's headquarters, where he was held for several hours. (RSF, 2014b)
\end{abstract}

Benjamin Ismaïl, head of RSF's Asia-Pacific desk, said: 'We condemn this violence and censorship of local journalists whose coverage of these demonstrations was in the public interest.' He also cited the ban on France 24 journalist Cyril Payen from future visits after an in-depth report by him on West Papua, and a violent attack by police on local Tabloid Jubi journalist Abeth You on 8 October 2015 while covering a demonstration in Jayapura by a group called Solidarity for Victims of Human Rights Violations in Papua. Police also arrested and questioned two fixers working for a French journalist, according to Ismaïl.

It is highly appropriate then that two of the articles in this PJR collection should deal with human rights and freedom of expression violations in West Papua.

$\mathrm{T}$ HIS edition opens with a commentary by Johnny Blades, New Zealand's first radio journalist to visit West Papua in five decades. He concludes: 'The labyrinthine process of applying for a journalist visa was a warning that change does not happen overnight for West Papua media freedom. On the ground, it is a risky business for a journalist covering West Papua.' Blades also pays tribute to Tabloid Jubi editor Victor Mambor, who features on PJR's cover, in his tireless crusade for the human rights of West Papuan people and journalists.

Ricardo Morris, president of the Fijian Media Association and editor of Repúblika, follows with a commentary about the reality of media life in Fiji after the September 2014 general election while the notorious Media Industry Development Decree 2010 remains in force. Researched and written while he was on a fellowship at the Reuters Institute for the Study of Journalism at Oxford University, Morris says their challenge is to 'recognise the façade of democracy' that has descended on Fiji and to 'peel it back'. 
West Papua is again the subject of the first research article in this edition, with academic and author Jason MacLeod writing about citizen media and civil resistance in the region that he has specialised in for many years. He concludes with some optimism for the future as global attention grows: 'The movement has matured into a coordinated international force, committed to a strategy of nonviolent resistance and diplomacy with citizen media at its heart.'

Alexandra Wake examines the risks and dangers facing young, mostly freelance, journalists who have absorbed Western news values - 'including the myth of the heroic war reporter and truth seeker' - and argues for greater understanding of the cultural and political nuances of countries from which they intend to report. She says media educators need to also pay more attention to risk-assessment skills, including sufficient pre-deployment training.

The framing of asylum seekers in the Australian news publications The Australian and The Guardian Australian Edition during their coverage of the riots at the Manus Island processing centre, Papua New Guinea, in February 2014, is the topic of the next article. Writing about this framing, Katherine Ellis, Janet Fulton and Paul Scott of the University of Newcastle found major differences in the framing of the riot by both newspapers and a ban by the Australian Department of Immigration and Border Protection on journalists having access to the centre was also influential in the reporting.

Concluding that democracy was no longer a 'foreign flower' in Tonga following the 2014 general election, Philip Cass of Unitec in Auckland explores the influence of the diasporic media, the attitudes of the Tongan community in Auckland and the views of the online community and concludes that they all contributed to the change that brought 'Akilisi Pohiva to and the Democracts to power in the kingdom.

Georgios Terzis of the European Union's INFOCORE Project on conflict and war reporting examines the evolution of media in conjunction with activism, from traditional media ethno-political conflict reporting, to today's whistleblowers and hacktivists who use the internet as their main platform.

Gregory Treadwell of AUT University's School of Communication Studies explores scepticism among journalism practitioners and researchers about the 'realpolitik success' of freedom of information regimes, especially a tendency towards state secrecy since the declaration of the so-called war on terror. He also considers literature specifically about New Zealand's Freedom of Information regime.

A reporting field trip by Australian journalism students to New Caledonia and Vanuatu in mid-2014 produced markedly differing impressions of the neighbouring island societies, linked to their 'independence' status - one as an integrated territory of France, the other as an independent state. Lee Duffield, the course coordinator of Queensland University of Technology, synthesises the collected work from the field, producing a thematic statement of findings, ranging from 
unresolved conflicts to the problems of development.

Alan Cocker, head of AUT's School of Communication Studies, has studied Malcolm Ross, New Zealand's first official war correspondent. However, in contrast to other research about his role, this article examines his less-known work as a photographer. Cocker asks whether in a multi-skilled digital era, 'the role of the writer and image-taker are still two different and not necessarily complementary skills'.

The last edition of PJR did not feature any Frontline reports, the section edited by Professor Wendy Bacon and featuring journalism as research, but this issue carries two such reports. The first, by Kayt Davies of Edith Cowan University, features Tracking Onslow, a collaboration between a university and local government that used journalism as a methodology to 'document and interrogate the interaction' between Chevron, the state and local governments and the Onslow community in the Pilbara region of Western Australia in a three-year 'secret deal' involving A $\$ 250$ million.

The other Frontline section features the Rainbow Warrior, secrecy and state terrorism and how an iconic act of French state terrorism in 1985 inspired a major microsite - a community-driven collaborative project in 2015 with a specialist Pacific community publisher. Written by David Robie of the Pacific Media Centre, the article details how the project interrogated participants over a three-decade period and "challenged the nature of mainstream media in New Zealand' with an alternative reader's media model.

The final research articles in the edition feature an examination by Ruth Callaghan of the challenges and opportunities provided by the news curation tool Storify in a journalism school newsroom, and a study by Trevor Cullen and Ruth Callaghan of an Edith Cowan University journalism pilot collaboration with the West Australian AIDS Council comprising media training and education programmes to share model frameworks about sexually transmitted diseases.

$$
\text { * } \quad * \quad *
$$

THE NEXT edition of Pacific Journalism Review (22(2)) will feature AsiaPacific strategies in journalism education with many papers being presented at the 4th World Journalism Education Congress (WJEC) and the Journalism Education and Research Association of Australia (JERAA), Pacific Media Centre (PMC) and Media Educators Pacific (MEP) Preconference collaboration in Auckland in mid-July. This edition will be edited by associate editor Philip Cass as David Robie will be on research leave. It will also be published later than the usual second semester edition time, coming out in December. 


\title{
References
}

Archdiocese of Brisbane (2016, May 1). 'We will lose everything': A report on a human rights fact finding mission to West Papua. Conducted by the Catholic Justice and Peace Commission, Archdiocese of Brisbane. Retrieved on May 3, 2016, from https:// cjpcbrisbane.files.wordpress.com/2016/05/we-will-lose-everything-may-2016.pdf

Freedom House (2015). Freedom of the press: Indonesia. Retrieved on May 21, 2016, from https://freedomhouse.org/report/freedom-press/2015/indonesia

Korman, V. (2016, May 18). Papua: Pricking our national conscience. The Jakarta Post. Retrieved on May 21, 2016, from www.thejakartapost.com/news/2016/05/18/papuapricking-our-national-conscience.html

Reporters Sans Frontières (RSF) (2016a). West Papua and visas. RSF Index 2016. Retrieved on May 21, 2016, from https://rsf.org/en/indonesia

Reporters Sans Frontières (RSF) (2016b). RSF tells Indonesia to stop flouting journalists' rights in West Papua. Retrieved on May 21, 2016, from https://rsf.org/en/ news/rsf-tells-indonesia-stop-flouting-journalists-rights-west-papua

Robie, D. (2014, July 30). Cross party support in NZ Parliament for 'media freedom' in West Papua. Café Pacific. Retrieved on May 21, 2016, from http://cafepacific. blogspot.co.nz/2014/07/cross-party-support-in-nz-parliament.html

Robie, D. (2013). Conflict reporting in the South Pacific: A critical reflexive approach to Timor-Leste and West Papua. Media Asia, 40(2), 147-161.

\author{
Professor David Robie \\ Editor \\ Pacific Journalism Review \\ Pacific Media Centre \\ www.pjreview.info
}

